\title{
Influence of Spartina alterniflora on structure and temporal variability of macrobenthic associations in a tidal flat of Paranaguá Bay (southeastern Brazil)
}

\author{
Paulo da Cunha Lana, Claudia Guiss \\ Centro de Biologia Marinha, Universidade Federal do Paraná, 83200 Pontal do Sul, Paraná, Brazil
}

\begin{abstract}
Structure and temporal variability of macrobenthic associations at vegetated and unvegetated sites of a Spartina alterniflora marsh were analyzed over a 14 mo period in the euhaline, highenergy sector of Paranaguá Bay (southeastern Brazil). The vegetated site was characterized by significantly higher numbers of species, mean densities and faunal dominance. The presence of plant cover affects epifaunal grazers, such as the gastropods Neritina virginea, Littorina flava and the isopod Sphaeromopsis mourei, besides a number of infaunal dominants associated with the root-rhizome mat, such as the polychaetes Isolda pulchella and Nereis oligohalina. Seasonal patterns of change were evident at both sites, with higher macrofaunal densities coinciding seasonally with higher availability of plant litter and lower predation pressure. Macrobenthic populations were generally more persistent at the vegetated site, despite short-term or seasonal variations. At the unvegetated site, intense and unpredictable population shifts were exhibited by the numerical dominants Kalliapseudes schubarti and Corophium acherusicum. Differences in trophic organization were also evident, with a marked dominance of suspension-feeders at the unvegetated site. Our results suggest that (1) much of the spatial and temporal structure of macrobenthic associations in euhaline, high-energy flats of a subtropical estuary depends on the presence of plant cover, together with seasonal fluctuations in detrital input and predation pressure, and (2) knowledge of the interaction between plant cover and time is a prerequisite for useful data interpretation or hypotheses formulation in such environments
\end{abstract}

\section{INTRODUCTION}

The effects of structural elements such as plant cover on associations of benthic invertebrates may be considerable and can lead to marked faunal differences between vegetated and nearby unvegetated marine habitats. Although intertidal marshes and subtidal seagrass meadows are believed to exhibit similarities in their functional and structural roles (Orth et al. 1984), widely variable and even contradictory patterns of macrobenthic diversity and density have been described for those habitats. It has been shown that number of species and density of animals are significantly higher in seagrass meadows compared with nearby bare sites, due to higher habitat complexity, sediment stability, protection from predation, and food abundance provided by plant cover (Young et al. 1976, Orth 1977, Stoner 1980, Heck \& Thoman 1981, Lewis \& Stoner 1983, Orth et al. 1984). However, such a generalization cannot be extended to saltmarsh habitats. Some authors have considered saltmarshes as low-diversity or faunistically depauperate systems relative to nearby unvegetated sites (Wiegert \& Pomeroy 1981, Capehart \& Hackney 1989), while others have described patterns similar to those found in seagrass habitats (Rader 1984, Zimmerman \& Minello 1984, Jackson 1985).

The structure of saltmarsh associations is further complicated by marked temporal changes in ambient or biological factors. The existence of strong cyclical or aperiodical patterns of recruitment and mortality and of a number of adaptive strategies, ranked according to temporal and spatial persistence, has been recognized for individual species or associations in other estuarine habitats (Boesch et al. 1976). However, studies on seasonal dynamics or natural fluctuations of saltmarsh fauna are few (Subrahmanyam et al. 1976, Subrahmanyam \& Coultas 1980, Kneib \& Stiven 1982). 
Considerable research on saltmarsh invertebrate associations has long been conducted in temperate areas (Daiber 1977, 1982, Long \& Mason 1983, Kneib 1984). However, there have been very few studies concerning the subtropical or warm-temperate saltmarsh fauna of southern Brazil (Capitoli et al. 1978, Tararam \& Wakabara 1987, Takeda 1988), despite increasing awareness of the importance of this habitat in coastal ecosystems as residence, feeding, or breeding zones for fish and invertebrates. In this region, Spartina alterniflora marshes usually colonize mud flats or tidal creeks as narrow discontinuous belts in front of mangrove woodlands. Seasonal variation in standing crop and productivity of local saltmarshes have been studied in this area by Adaime (1978), Panitz (1987), Soriano-Sierra (1990) and Lana et al. (1991).

In this paper, we describe and compare the structure and seasonal variability of macrobenthic associations at vegetated and nearby unvegetated sites in a tidal flat colonized by Spartina alterniflora in Paranaguá Bay (southeastern Brazil). Species composition, abundance and persistence patterns are analyzed in relation to physical and biological factors which have been shown to be important in the distribution of saltmarsh invertebrates, such as substrate, temperature, salinity, detrital availability, and plant cover.

\section{MATERIALS AND METHODS}

Paranaguá Bay is a semi-enclosed estuarine system bounded by mangroves and saltmarshes, located in the State of Paraná, southeastern Brazil (Fig. 1). Local tides are characterized by diurnal inequality and an almost semi-diurnal pattern in maximum tidal amplitudes (ca $2 \mathrm{~m}$ ). Surface flood- and ebb-flows can attain velocities between 100 and $125 \mathrm{~cm} \mathrm{~s}^{-1}$ before high and low tides, respectively (Knoppers et al. 1987). Pure stands of Spartina alterniflora, ranging from high creekside to short mangrove-fringing formations, form the bulk of saltmarsh vegetation all around the Bay.

Two intertidal stations were established about $500 \mathrm{~m}$ northeast of Baguaçu tidal creek, in the euhaline, waveexposed sector of the Bay, near its southern access channel (Fig. 1). One station was located on a discontinuous monotypic belt of Spartina alterniflora varying from 5 to $30 \mathrm{~m}$ in width, and $600 \mathrm{~m}$ long. A second station was located at an adjacent site devoid of vegetation. Both stations were located at similar tidal levels [ca 10 $\mathrm{cm}$ below MHWN (mean high water of neap tides) ], with no visual differences in sediment nature.

Faunal and environmental samples were taken monthly at both stations from May 1987 to June 1988. Temperature ( $\mathrm{T}$ ) was determined at a sediment depth of 5 to $10 \mathrm{~cm}$. Salinity (S) of interstitial water was determined using a temperature-compensating refractometer. Sediment samples were analysed for percentage of silt-clay and mean grain size (Suguio 1973), and dried sub-samples were combusted at $550^{\circ} \mathrm{C}$ for $60 \mathrm{~min}$ in order to determine organic content (Dean 1974).

Faunal samples consisted of 5 randomly located replicates $(30 \times 30 \mathrm{~cm}, 12 \mathrm{~cm}$ deep), for a total monthly sample of $0.45 \mathrm{~m}^{2}$ at each site. Standing dead or alive culms and leaves of Spartina alterniflora were clipped at ground level and searched for epifaunal organisms. Sediment samples with the root-rhizome mat were

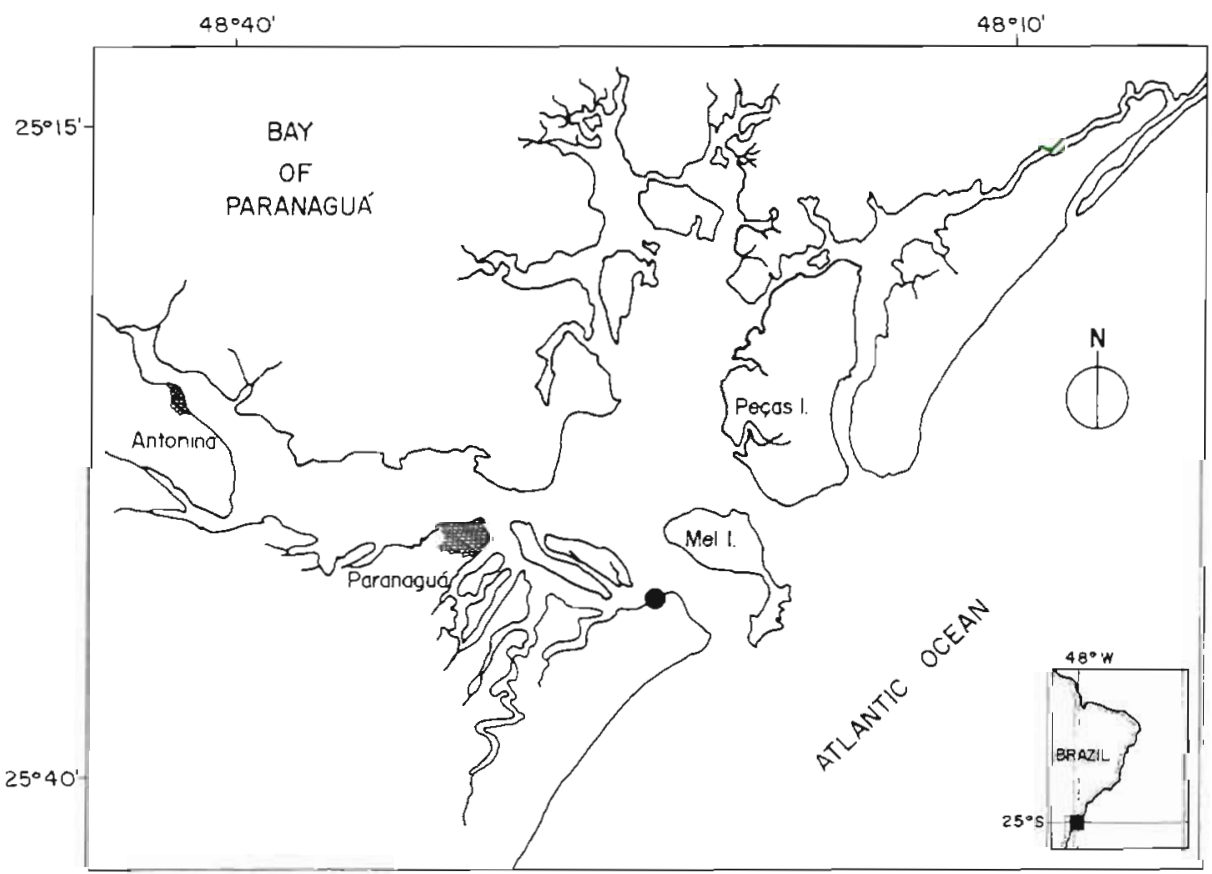

Fig. 1. Location of sampling site

(•) in Paranaguá Bay, Paraná State, southeastern Brazil 
sieved through $500 \mu \mathrm{m}$ and $1000 \mu \mathrm{m}$ meshes, fixed in $10 \%$ formalin and preserved in $70 \%$ alcohol. All specimens were identified at the lowest practical taxonomic level and counted under a dissecting microscope.

The number of species (s), density per $0.09 \mathrm{~m}^{2}(\mathrm{n})$, diversity (Shannon's index $H$ ) and evenness (Pielou's index $J$ ) were computed for each replicate in order to evaluate and compare faunal changes at both sites. Biological Importance (Sanders' BI, 1960) was determined by assigning scores to species in order of abundance in monthly samples and summing the scores for each species throughout the study period. The mean abundance of the 10 top-ranked species at each site was plotted against time in order to evaluate individual patterns of temporal change.

In order to assess temporal patterns of persistence, coefficients of variation were employed as a measure of individual species or association variation at a given site with time, as proposed by Sanders (1978).

Preliminary analysis showed that $\log (x+1)$ transformations were sufficient to reduce heterogeneity of the variances for subsequent statistical or numerical treatments. Two-way analyses of variance (ANOVA) were used in order to test for differences in environmental ( $T$, $\mathrm{S}, \phi$, silt-clay and organic content, using a randomized complete blocks design) and community parameters ( $s$, n, $H, J$, using ANOVA with replication) between habitat types (vegetated vs unvegetated habitats) and sampling periods. Time was considered a fixed factor because all available months were sampled, although mean values for granulometric data that were missing from June to August 1987 were interpolated.
In order to reduce the database to a more workable size, cluster analysis was applied to a frequency matrix of the 23 top taxa in terms of BI scores (with at least 3 individuals as the minimum total for inclusion and responsible for $86 \%$ of total macrofauna) and 28 samples ( 2 sites vs $14 \mathrm{mo}$ ). Species (R-mode) and monthly samples ( $Q$-mode) groups were determined using Czekanowski's index of similarity and the unweighted arithmetic average sorting strategy. Principal-component analysis was employed in order to reduce the multivariate nature of the data to a few interpretable dimensions. The data matrix included the 23 top taxa in terms of $\mathrm{BI}$ scores and 5 environmental variables (temperature, salinity, mean grain size, silt-clay and sediment organic content), contained in 28 cases (14 sampling months at each site). In dendrograms and factorial maps, each sample was identified by a first letter representing the source of the sample (V: vegetated; U: unvegetated), followed by the month and a 2 -digit number representing the year ( 87 or 88 ).

\section{RESULTS}

\section{Physical and chemical data}

Temporal variations in temperature, salinity and sedimentary parameters are shown in Fig. 2. Table 1 summarizes the variation range of environmental parameters at both sites, together with the results of 2-way ANOVAs.

Salinity variation did not show any clear seasonal

Table 1 Variation range of variables and results of 2-way ANOVA evaluating effect of site and time (May 1987 to June 1988) on dependent variables [vegetated (V) vs unvegetated (U)]. Randomized blocks analyses for physico-chemical parameters, and 2way ANOVA with replication for community parameters. Analyses performed on $\log (x+1)$ transformed data. NS: no significant differences, $p>0.05 ; \cdot 0.05>p>0.01 ; \cdots p<0.01 ; \cdots p<0.001$. Differences between sites determined by Scheffé post hoc comparisons

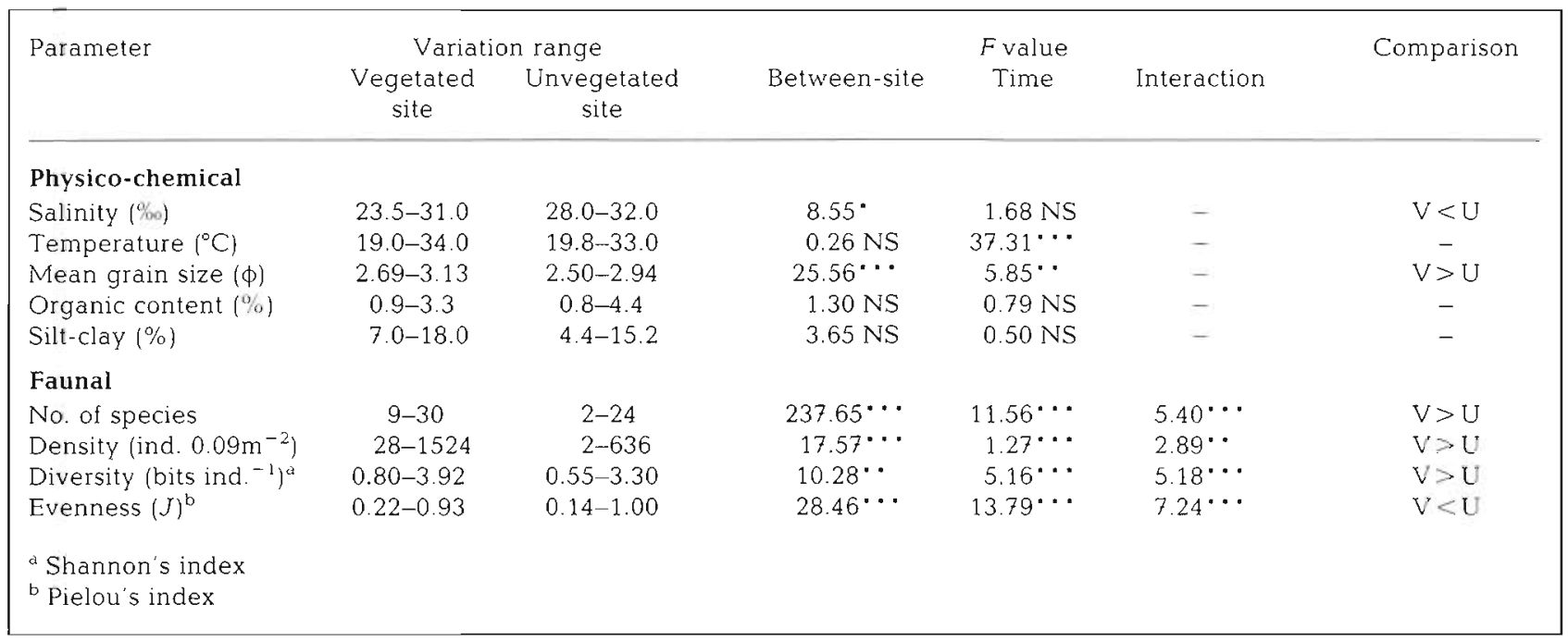


trend, as tested by 2-way ANOVA among months. However, average values were lower at the vegetated site $(p<0.01$, Table 1$)$, probably due to the formation of transient freshwater creeks or ponds after heavy rainfall in summer.

Sediment temperature values, which ranged from $19-20^{\circ} \mathrm{C}$ in winter to $33-34^{\circ} \mathrm{C}$ during late spring and summer, were statistically different between months $(\mathrm{p}<0.001$, Table 1$)$, but similar between sites.

Sediment mean grain diameter varied statistically between the 2 sites ( $p<0.001$, Table 1$)$ and among the sampling months ( $\mathrm{p}<0.01$, Table 1), having lower values (higher $\phi$ ) at the vegetated site during late spring and summer. Silt-clay percentage and sediment organic content were found to be statistically indistinguishable at the 0.05 significance level between stations and among months. However, the highest percentage of silt-clay $(18 \%)$ was recorded at the vegetated site. Sediment organic content varied between $0.8 \%$ (unvegetated site. November 1987) and $4.4 \%$ (unvegetated site, May 1987), with little overall pattern evident.

\section{Fauna}

A total of 28315 macrobenthic animals (22 929 at the vegetated site) representing 120 species (98 at the vegetated and 76 at the unvegetated area) were identified.

The polychaetes Isolda pulchella and Nereis oligohalina and the tanaidacean Kalliapseudes schubarti accounted for $70 \%$ of all individuals at both sites. I. pulchella is a small tube-building ampharetid usually associated with Spartina alterniflora roots and rhizomes and thought to be a surface- or subsurfacedeposit feeder. $N$. oligohalina is a discretely motile nereidid that probably also acts as a deposit-feeder. $K$. schubarti is a suspension-feeder that builds small tubes to $10 \mathrm{~cm}$ depth. Common epifaunal forms on S. alterniflora were the gastropods Neritina virginea and Littorina flava and the isopod Sphaeromopsis mourei.

Though most of these species were present throughout the study period, marked population fluctuations were evident as a rule, as shown by variations in mean density of the 10 top-ranked species (BI scores) at the vegetated (Fig. 3) and unvegetated (Fig. 4) sites.

Some fluctuations displayed a strong seasonal component, as shown in the epifaunal species Neritina virginea, Littorina flava and Sphaeromopsis mourei, which were more common in winter. In spite of being less abundant during summer, Isolda pulchella and Nereis oligohalina did not show such a clear seasonal trend (Fig. 3). Kalliapseudes schubarti showed a typically irruptive occurrence, appearing in high densities during the winter months of 1987 at the unvegetated site and disappearing thereafter. Most of the other species, such as the polychaetes Diopatra sp., Sigambra grubii and Glycinde multidens and the bivalves Sphenia antillensis, Lucina pectinata and Anomalocardia brasiliana, were persistent throughout the study period in spite of apparently aperiodical fluctuations (Figs, 3 \& 4)

Macrofaunal density varied from 2.0 ind. per $0.09 \mathrm{~m}^{2}$ (unvegetated site, November 1987) to 1524 ind. per $0.09 \mathrm{~m}^{2}$ (vegetated site, June 1987). Faunal numbers were significantly higher at the vegetated site than at the unvegetated site throughout the study period ( $p<0.001$, Table 1). The only exception was July 1987 , when total densities were roughly similar, due to a peak of Kalliapseudes schubarti. At both sites, mean densities were usually higher in winter compared with warmer months ( $p<0.001$, Table 1 and Fig. 5).

Highly significant differences in number of species ( $p<0.001$, Table 1) occurred between the sites, with $a$ higher number at the vegetated area (up to 30 species in a replicate in July 1987). Significant temporal differences were evident at both sites ( $p<0.001$, Table 1 ). Temporal variations in number of species, usually higher in colder months at both sites, are shown in Fig. 5 .

Diversity and evenness were also statistically different between sites ( $p<0.01$, Table 1 ); diversity was higher but evenness was lower at the vegetated site. Despite significant temporal differences at both sites (Table 1), there was no clear seasonal pattern (Fig. 5). Monthly values appeared to reflect the numerical density of dominant species rather than species richness at each site.

The interaction between plant cover and time was highly significant for all tested community parameters $(p<0.001$ or $p<0.01$, Table 1$)$. This indicates that the effects of both factors are not additive, and are dependent on each other

Coefficients of variation for the 42 top-ranked species at the vegetated site and the 29 at the unvegetated site (accounting together for $99 \%$ of total individuals) were plotted in order of increasing value (Fig. 6). Coefficients of variation at the vegetated site ranged from about 50-75\% (for Sigambra grubii, Neritina virginea, Nemertinea sp., Lucina pectinata, Nassarius vibex, Macoma constricta, and Sphaeromopsis mourei) to more than $250 \%$ (for Ampithoe ramondi, Polychaeta sp., Laeonereis acuta and Chthamalus proteus). The grand mean for the 42 top-ranked species was $145 \%$ (Fig. 6). At the unvegetated site, coefficients of variation ranged from about $75-100 \%$ (for Diopatra sp., Lucina pectinata, Tagelus divisus, Sigambra grubii, and Nereis oligohalina) to more than $275 \%$ (for Kalliapseudes schubarti, Corophium acherusicum, Polydora socialis, Branchiostoma sp., Haminoea elegans 


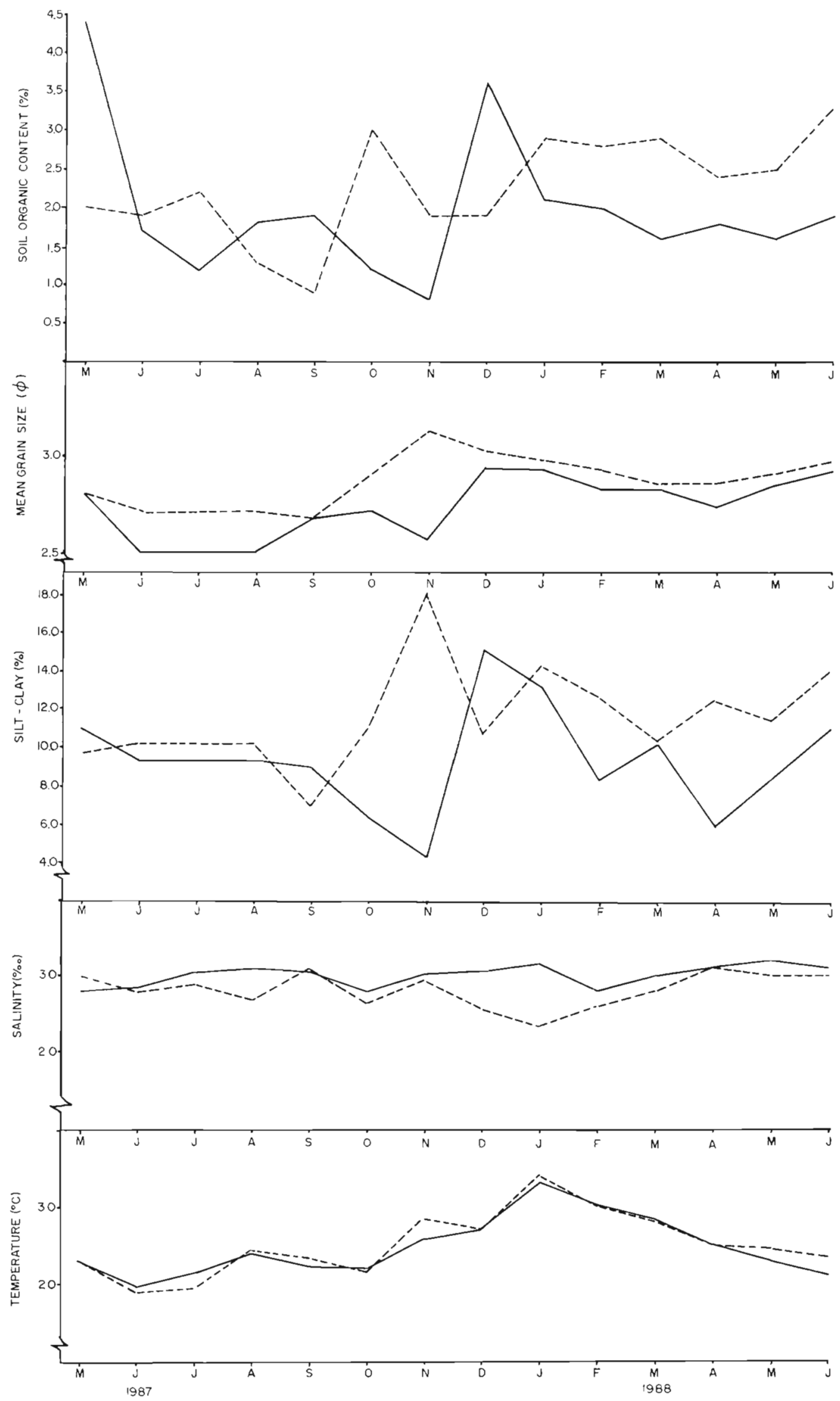

Fig. 2. Temporal variation in temperature, salinity and sedimentary parameters at the (--- -) vegetated and ( - ) unvegetated sites from May 1987 to June 1988 


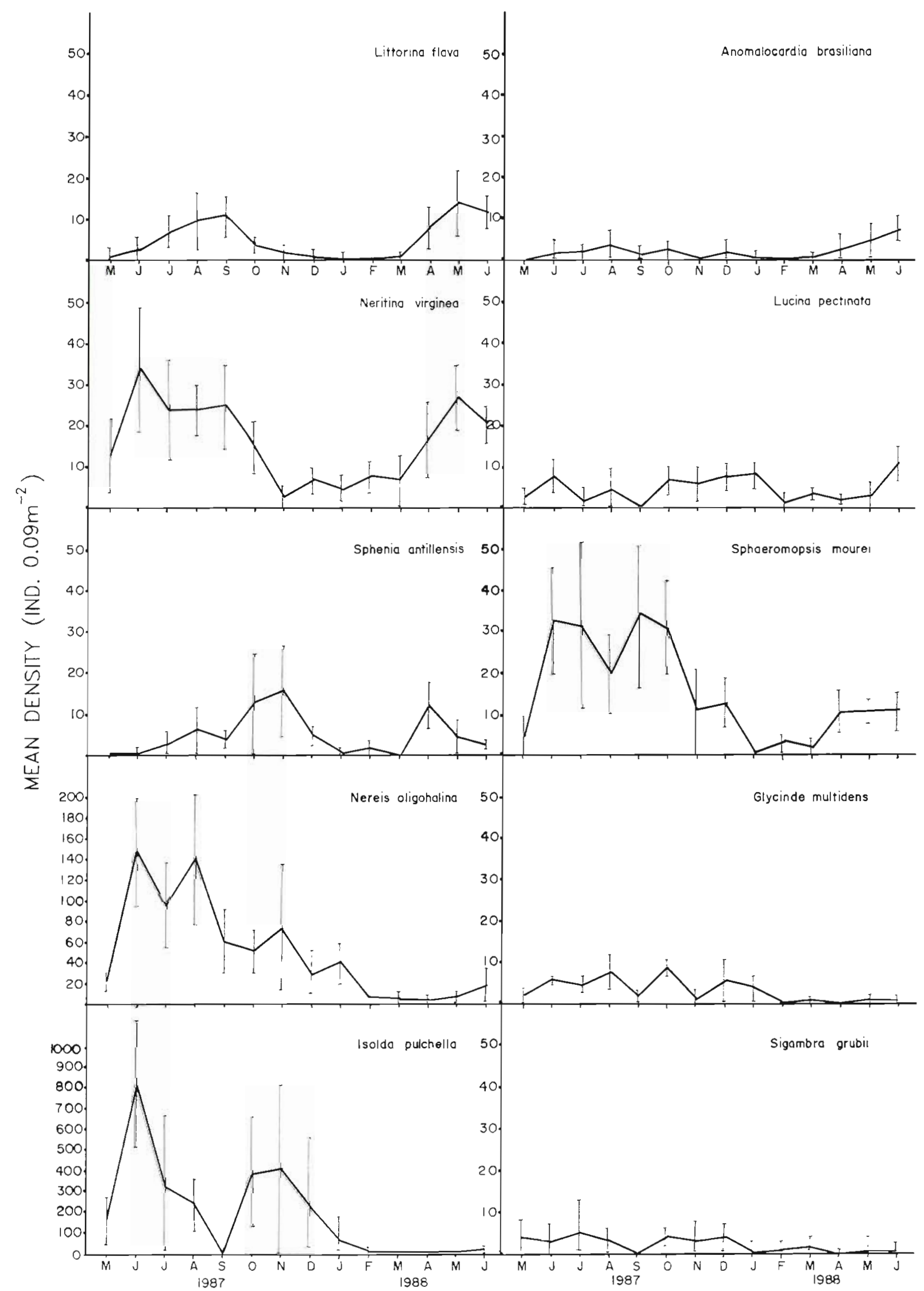

Fig. 3. Temporal variation in numerical density (ind per $0.09 \mathrm{~m}^{2}$ ) of the 10 top-ranked species (Sanders' Biological Importance Index, 1960) at the vegetated site from May 1987 to June 1988 


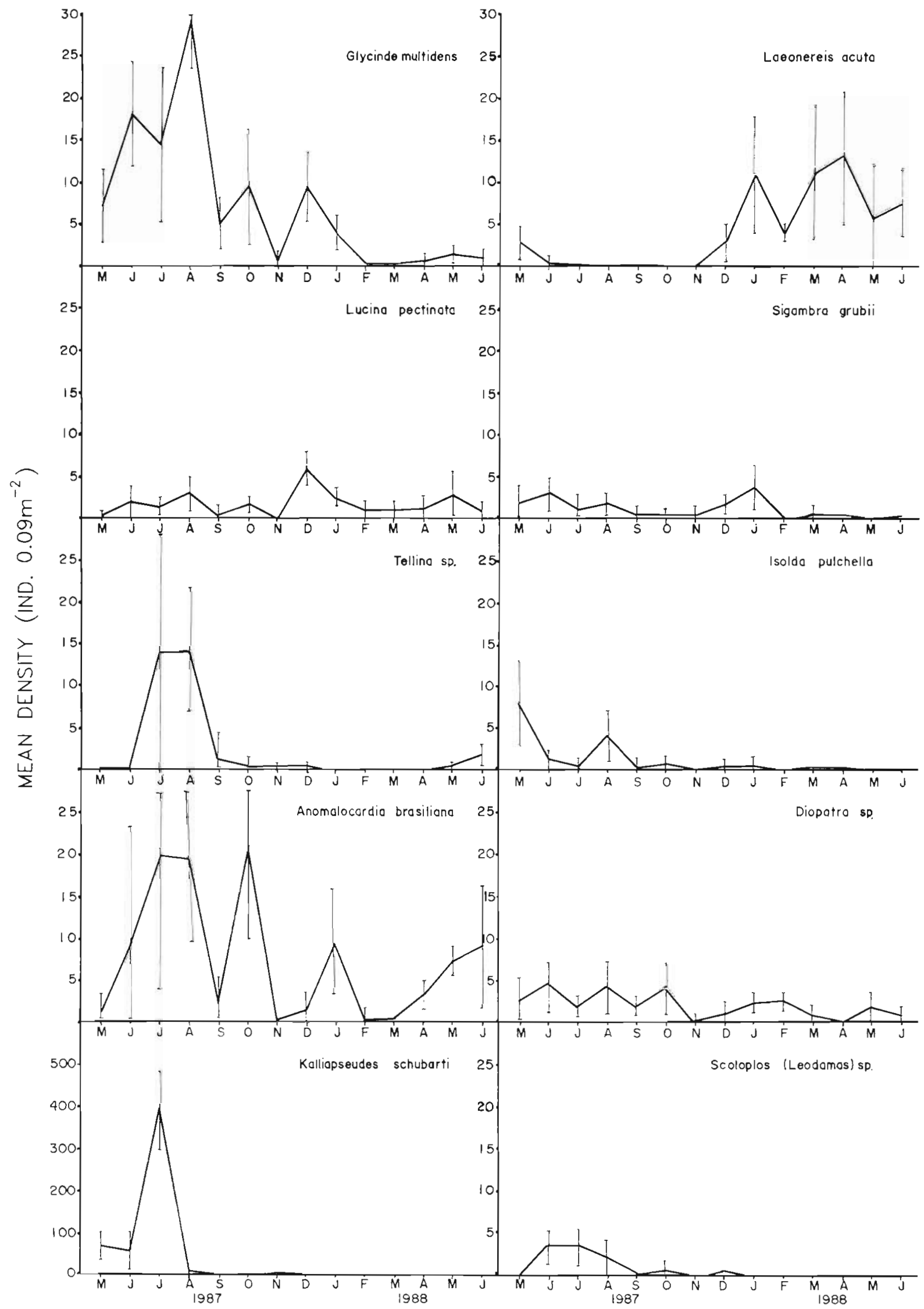

Fig. 4. Temporal variation in numerical density (ind. per $0.09 \mathrm{~m}^{2}$ ) of the 10 top-ranked species (Sanders' Biological Importance Index, 1960) at the unvegetated site from May 1987 to June 1988 


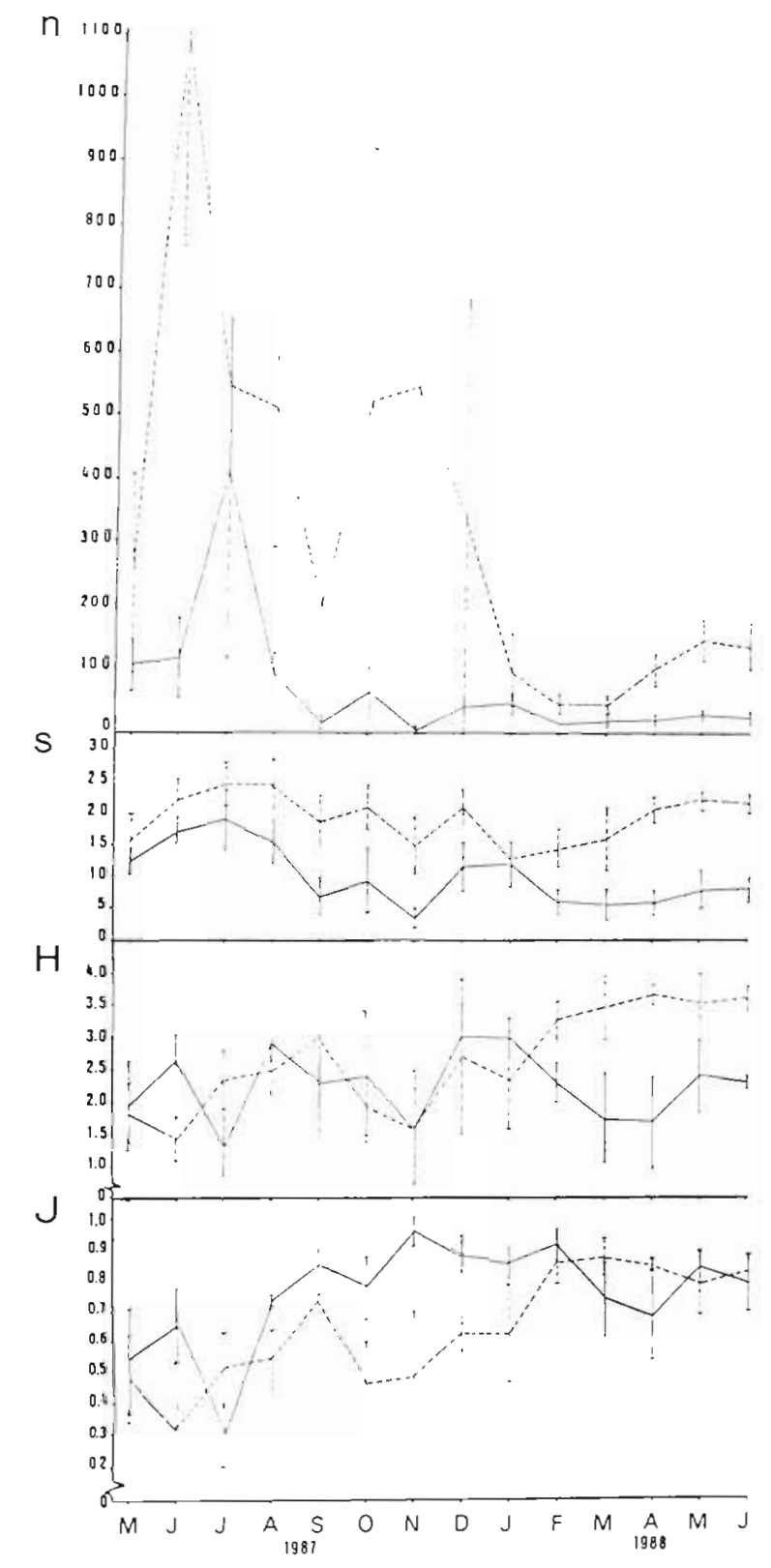

Fig. 5. Temporal variation in mean density $(\mathrm{n})$, number of species $(s)$, diversity $(H)$ and evenness $(J)$ per $0.09 \mathrm{~m}^{2}$ of benthic macrofauna at the (--) vegetated and $(-)$ unvegetated sites from May 1987 to June 1988

and Pseudonereis sp.), with a grand mean of $197 \%$ (Fig. 6). Differences between grand means were significant at the 0.05 level ( $t$-test).

Inverse analysis of data from 14 mo yielded 3 coherent species groups at a $45 \%$ similarity level (Fig. 7 a). Group A: The epifaunal species Neritina virginea, Sphaeromopsis mourei, Littorina flava, Bittium varium and Parhyalella whelpleyi, and the infaunal polychaetes Isolda pulchella and Nereis oligohalina, mostly confined to the vegetated site. Group B: The polychaetes Sigambra grubil, Glycinde multidens,
Capitella capitata and Diopatra sp., and the bivalves Lucina pectinata, Anomalocardia brasiliana, Sphenia antillensis, and Macoma constricta, found at both sites, although more common in one or the other. Group C: The polychaetes Scoloplos (Leodamas) sp. and Heteromastus similis and the bivalve Tellina sp., largely confined to the unvegetated site

The crustaceans Upogebia brasiliensis, Kalliapseudes schubarti and Corophium acherusicum, the polychaete Laeonereis acuta and the gastropod Acteocina bidentata were not grouped, probably due to their temporally discontinuous occurrence. However, $K$. schubarti, C. acherusicum and $L$. acuta were much more common at the unvegetated site.

Classification analysis of sampling times (Fig. 7b) indicated that groups were formed primarily on the basis of spatial similarity or macrofaunal peak densities and only secondarily by temporal patterns of variation within a given site. Two groups were evident at the $35 \%$ similarity level, one consisting of vegetated samples and the other of unvegetated samples. The one exception was the sample U Nov 87, practically devoid of macrofauna, and not grouped with the other samples from the same site or season. At the $55 \%$ level, winter and summer samples from the unvegetated site were differentiated. The exceptions were U May 88 and U Jun 88 , which grouped with the warmer months. Winter and late spring/summer groups from the vegetated site were differentiated only at the $80 \%$ similarity level.

In order to facilitate interpretation of principal-component analysis, sample points and parameter points were projected simultaneously on a similar scale in the factorial space to clarify affinities of species to the samples and environmental factors (Fig. $8 \mathrm{a}, \mathrm{b}$ ). There was a broad match with the overall pattern of responses evidenced by cluster analysis. The first component accounted for $29.6 \%$ of the total variance. Species belonging to Group A, such as Nereis oligohalina, Isolda pulchella and epifaunal forms from the vegetated site, with negative coordinates, were opposed to species from Groups B (transitional) and $C$ (vegetated site), with positive coordinates. This axis also separated winter and early spring samples from both sites, essentially correlated with macrofaunal peaks of abundance (vegetated samples with negative and unvegetated samples with positive coordinates). Physico-chemical parameters and summer samples contributed poorly to this first component. Species position on the first axis (PC I) can be regarded as a clear response to either presence or absence of plant cover. The second component ( $17.3 \%$ of data variance) separated summer conditions (higher temperature, lower mean grain size and summer samples, with positive coordinates) from winter/spring conditions (lower temperature, higher mean grain size and higher macrofaunal densities at both sites). Interpretation of the third 
and fourth components, which together accounted for $20.5 \%$ of total variance, was not so clear. On PC III the species responded primarily to sedimentorganic content and secondarily to mean grain diameter and temperature, as shown by the positive contribution of these parameters. However, the secondarily dominant Lucina pectinata was the only species which clearly responded to these variables. On PC IV, epifaunal species on Spartina alterniflora blades, such as Bittium varium and Parhyalella whelpleyi, with positive coordinates, were further separated from infaunal species associated with S. alterniflora roots and rhizomes, such as $N$. oligohalina, or to burrowing ones, such as Upogebia brasiliensis and Capitella capitata, with negative coordinates.

\section{DISCUSSION}

It has been previously suggested that saltmarshes display a lack of faunal diversity and low macrofaunal

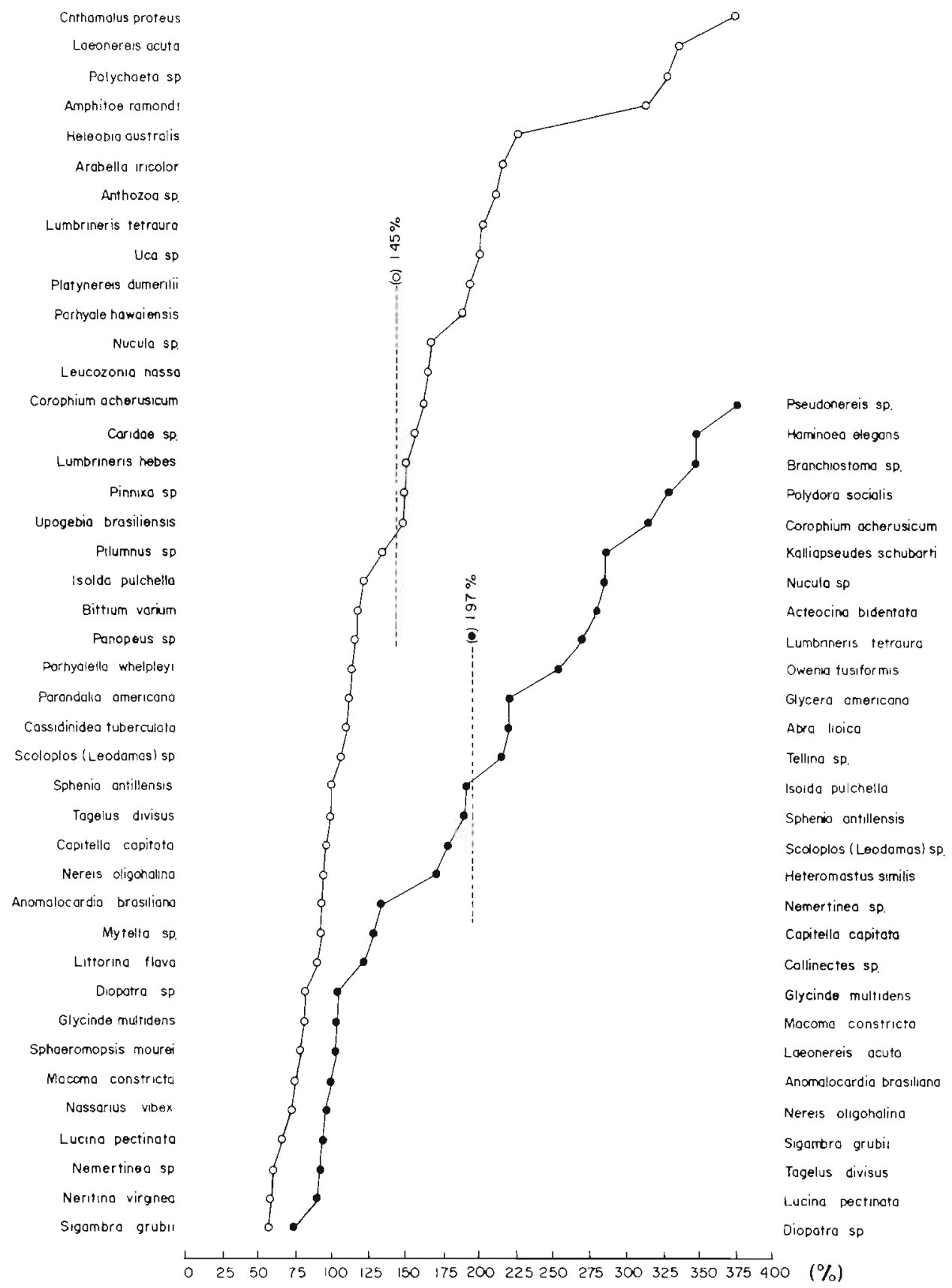

Fig. 6. Cumulative plotting of coefficients of variation for (o) the 42 top-ranked species at the vegetated site, and ( $\bullet$ the 29 topranked species at the unvegetated site 


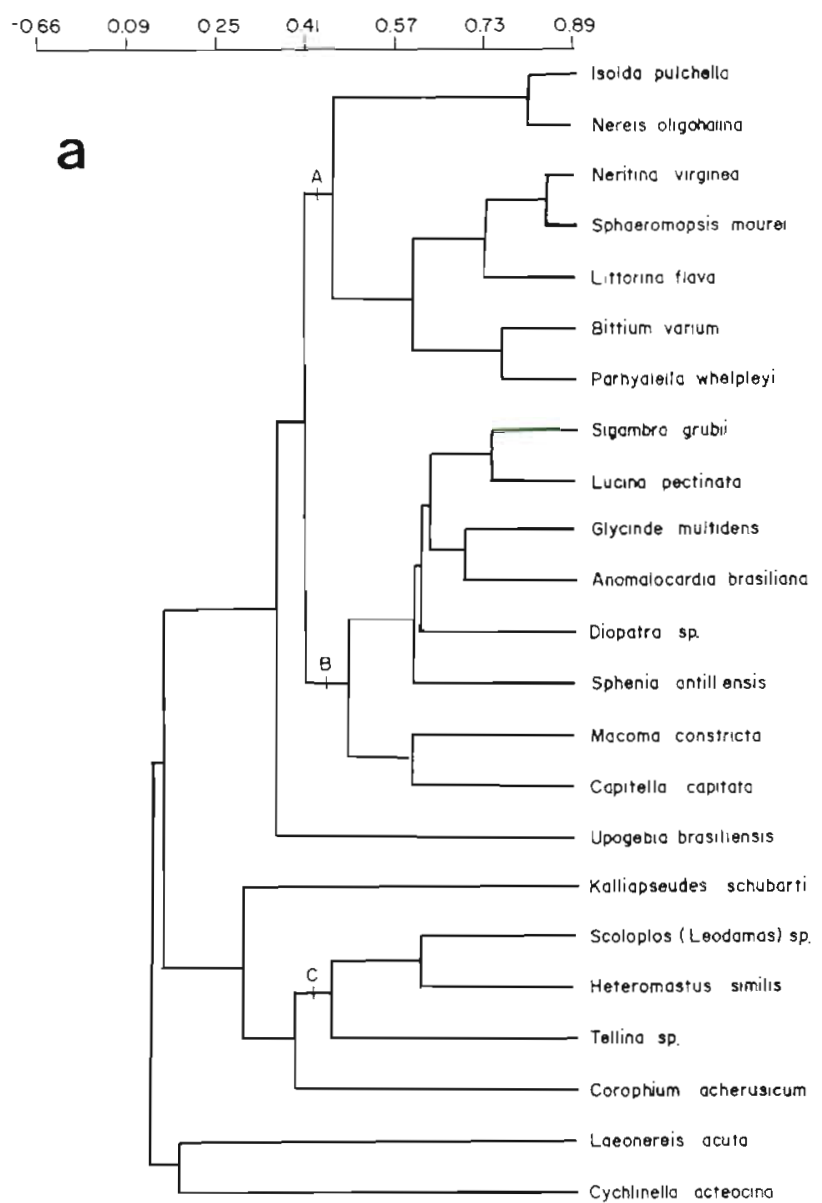

Fig. 7. Similarity dendrograms of (a) species and (b) sampling months at vegetated (V) and unvegetated (U) sites in 1987 and 1988. Species Groups $A$ to $C$ indicated in (a)

numbers relative to nearby submerged or bare areas (Capehart \& Hackney 1989). We present some evidence that an intertidal marsh can in fact play a major role in structuring macrobenthic communities of a high-energy, subtropical tidal flat, similar to that played by subtidal grasses. Relative to the unvegetated sites, the total number of species, mean densities and faunal dominance were significantly higher at sites colonized by Spartina alterniflora. Despite a certain homogeneity in sedimentological and hydrological characteristics, each site exhibited a distinctive community organization, with few very abundant species, the remaining ones represented by small populations. Small-scale aggregations of infaunal organisms have been shown to exist in association with single stems and groups of stems of saltmarsh vegetation (Rader 1984). In the present study, this was the case for the infaunal polychaetes Isolda pulchella and Nereis

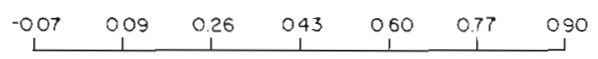

b

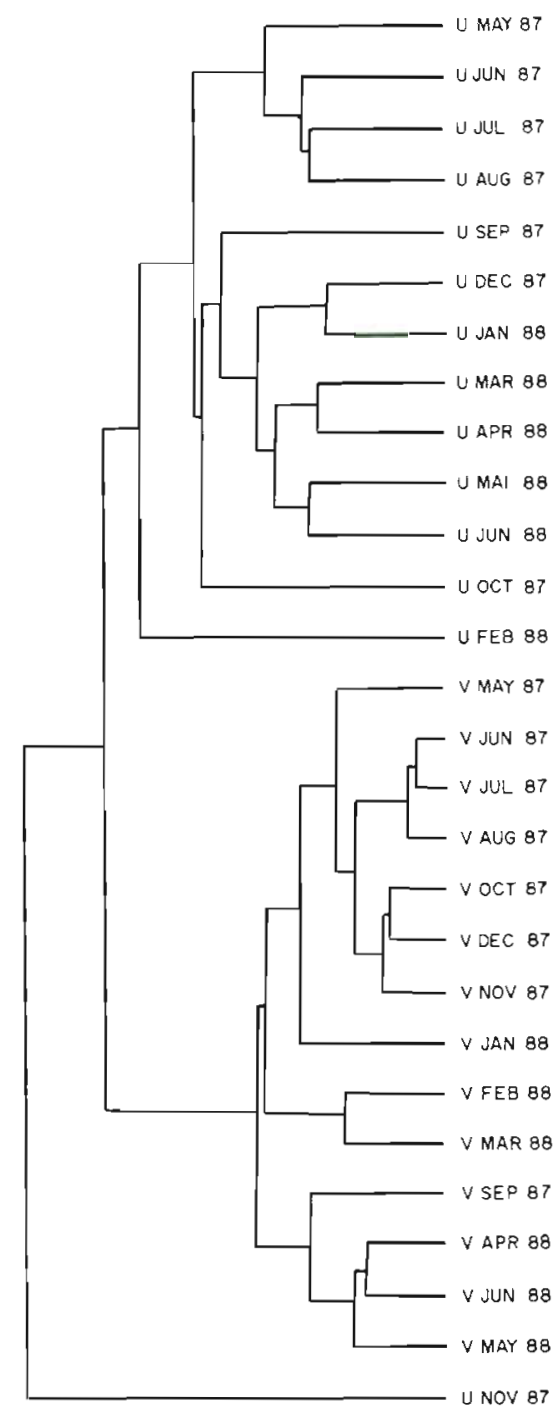

oligohalina, positively correlated with plant biomass and scarce in nearby bare sediments. Plant cover can change the sedimentary environment in marine habitats and potentially affect the composition of infauna by baffling currents or waves and modifying the dynamics of organic-matter input and sedimentation. The high densities of infaunal polychaetes at the vegetated site were probably related to the shelter or food provided by plant structures. Furthermore, it has also been shown that $S$. alterniflora roots and rhizomes can contribute actively to sediment oxygenation, thus enhancing faunal colonization (Teal \& Wieser 1966).

Further between-habitat differences were introduced by the increased surface area at the vegetated sites, as well as by the higher habitat complexity above the sediment and algal or detrital films developed on Spartina alterniflora culms and used as food for grazers. Above-ground plant structures supported a rich 

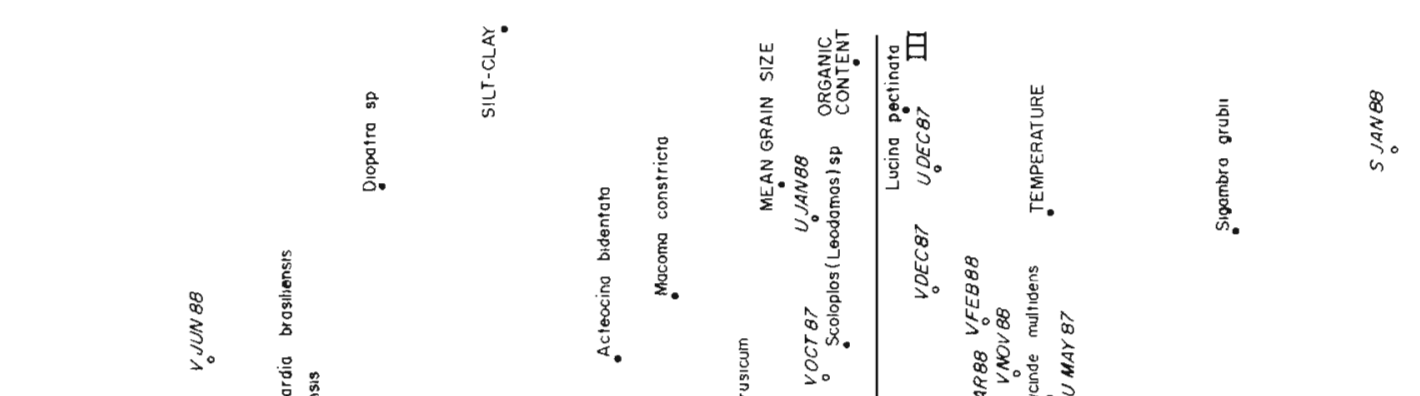

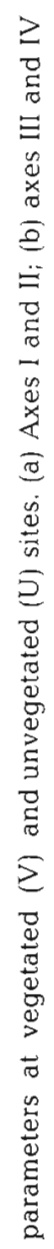

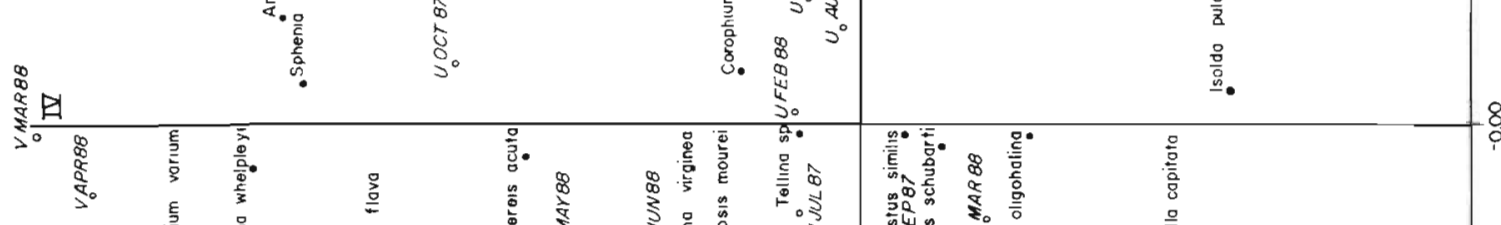

م 8
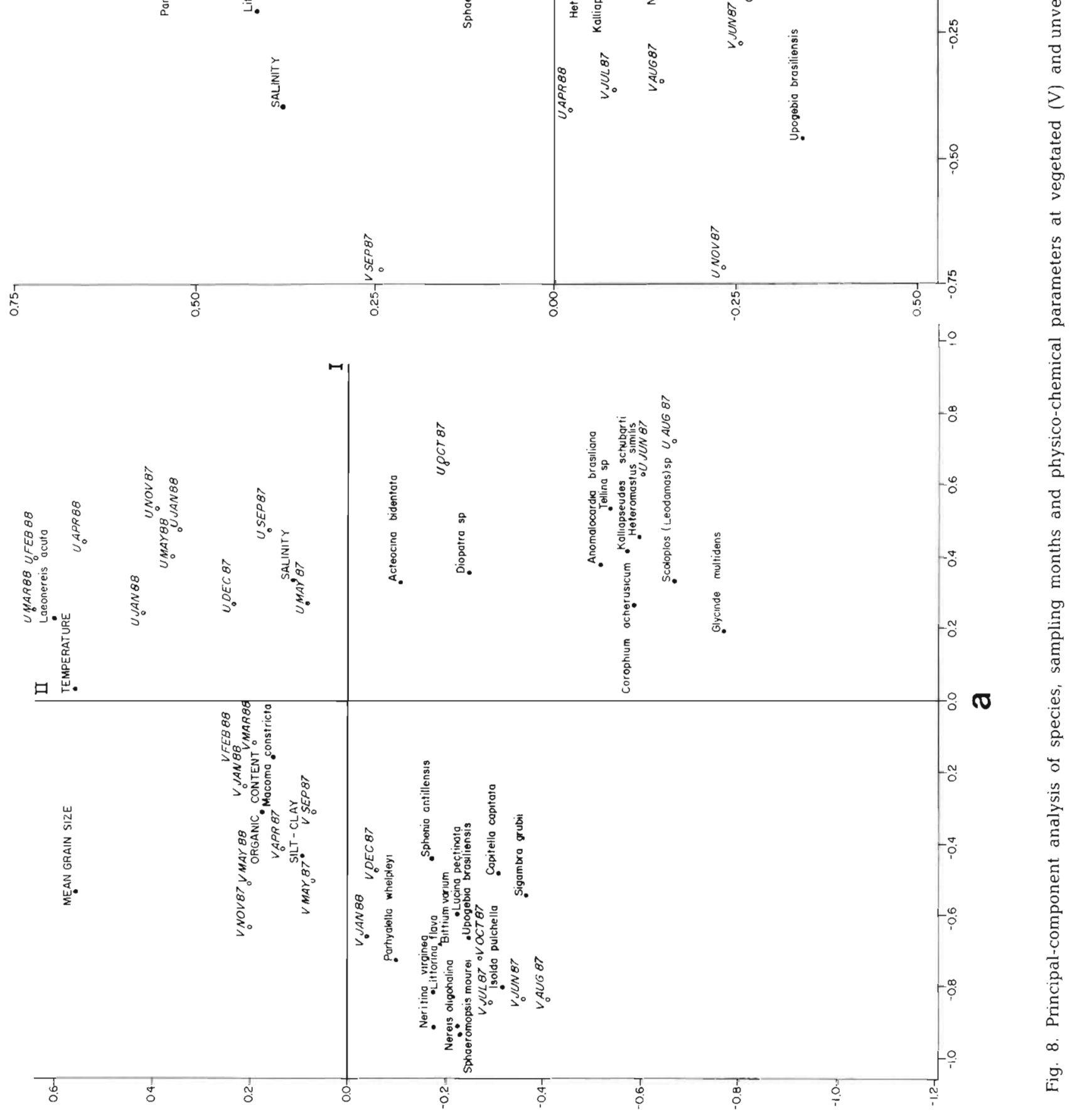
epifauna dominated by the gastropods Neritina virginea and Littorina flava and the isopod Sphaeromopsis mourei, which depend physically on the blades as a habitat and are not usually found at unvegetated sites. Higher epifaunal densities at vegetated sites relative to nearby unvegetated sites have been extensively reported for seagrass beds (Orth 1977, Stoner 1980, Orth et al. 1984).

In striking contrast to the vegetated site, the number of species, macrofaunal densities and faunal dominance were comparatively low at the unvegetated site. Species composition of the local association, much less predictable in space or time, was characterized by the irruptive suspension-feeders Kalliapseudes schubarti and Corophium acherusicum, in addition to the polychaetes Laeonereis acuta (presumably a detritusfeeder) and Diopatra sp. (presumably a carrion-feeder). Three general hypotheses could explain this reproducible abundance pattern: (1) epifaunal species living on leaves or infaunal species associated with the rootrhizome mat are obviously excluded in the absence of adequate substrata for attachment, sheltering and feeding; (2) absence of plant cover can result in reduced detrital input to grazers or to sediment-dwelling fauna, limiting the number of deposit-feeders; and (3) as previously established, roots and rhizomes of seagrasses and saltmarshes can prevent certain types of infauna, such as tube-builders or large burrowers, from residing within the bed, due to root interference with faunal movement (Stoner 1980, Brenchley 1982, Capehart \& Hackney 1989).

Changing patterns of community structure were greatly influenced by the population dynamics of the dominant species Isolda pulchella, Nereis oligohalina and Kalliapseudes schubarti. Species diversity and evenness, although significantly different between sites and among months, did not show any clear seasonal pattern, despite the higher species numbers and faunal dominance at the vegetated area. Such indices could not be considered reliable tools for assessing temporal variability or for making between-habitat comparisons. The Shannon formula is reported to be most sensitive to changes in the importance of rare species in samples (Peet 1974). However, this information index was strongly influenced by the evenness component, and it masked clear spatial or seasonal trends in species richness.

The abundance and number of species in local associations displayed a distinct pattern of seasonal change, with higher densities in colder months, followed by a marked decline of most populations during summer. Although few detailed studies of temporal variability in abundance and diversity of saltmarsh invertebrates have been carried out, seasonal patterns have also been observed in the southeastern USA (Sub. rahmanyam et al, 1976, Bell 1979, 1980, Kneib \& Stiven 1982, Kneib 1984).

Seasonal or short-term changes in benthic populations did not correlate with changes in sedimentary parameters and were probably a reflection of food availability, species-specific reproductive processes or changes in predation intensity throughout the year. Contrary to what occurs in nearby subtidal environments (P. C. Lana \& H. H. Sovierzoski unpubl. data), the density of local macrofauna, consisting mostly of surface or subsurface deposit-feeders, was significantly higher during the colder months of the year (June to September). The highest macrofaunal densities coincided seasonally with a higher availability of plant litter or detritus. Litter is introduced into the local system in the form of dead leaves or stems associated with Spartina alterniflora beds. Detrital availability, expressed as the biomass of dead above-ground plant material, was shown to be significantly higher in winter, probably reflecting higher mortality rates of S. alterniflora (Lana et al. 1991). A similar pattern was observed by Takeda (1988) and, less conclusively, by Tararam \& Wakabara (1987) for the benthic fauna of saltmarshes in the Cananéia region, about $100 \mathrm{~km}$ north of our study site. Changes in food resources as detrital input have also been considered a potential source of seasonality in macrobenthic populations of seagrasses (Bloom 1983).

The complex relationship between food availability and macrofaunal density as a whole seemed to be further complicated by an inverse temporal trend in predation pressure. Mean densities were lower in summer, probably because of a correspondingly lower availability of detritus (Lana et al. 1991), coupled with higher predation rates. Although the influence of predation was not experimentally assessed, we observed during field work in the warmer months a remarkable increase in the activity of natant or demersal predators, such as the fishes Bathygobius soporator, Guavina guavina and Sphoeroides spp., and the blue crabs Callinectes sapidus and $C$. danae. Summertime infaunal decline has been also attributed to a higher abundance of natant predator components in the eastern USA (Peterson \& Peterson 1979, Kneib 1984, Wiltse et al. 1984).

Individual species or the macrobenthic association generally exhibited higher persistence at the vegetated site, despite well-marked seasonal or short-term variations which were evident even in the densities of numerically dominant species. This pattern can be attributed to the buffering capacity of plant structures, at the surface as well as the subsurface. Plant cover attenuates physical or biological disturbance, providing shelter, slowing the reworking or removal of substrate and reducing predation pressure and unpredictability in production and input of organic matter In 
contrast, population shifts were more intense and unpredictable at the unvegetated site, as shown by the higher coefficients of variation exhibited by the numerical dominants Kalliapseudes schubarti and Corophium acherusicum. This finding supports the general prediction that associations dominated by suspension-feeders should show greater fluctuations than those dominated by deposit-feeders, as a result of unpredictability in food availability (Levinton 1972). Population fluctuations were not related to cyclical changes in sediment parameters, which were relatively stable throughout the study period. Numerically dominant species at the unvegetated site occurred typically in dense patches, discontinuous in time or space. Opportunistic or irruptive strategies have been previously suggested as advantageous at sites with low macrophyte biomass, which are more susceptible to high rates of predation or environmental disturbance (Peterson \& Peterson 1979, Stoner 1980). On the other hand, biogenic structures in saltmarshes may protect fauna from disturbing agents, such as predators or adverse ambient conditions, allowing for increased specialization of feeding habits (Orth 1977, Kneib 1984).

Interaction between plant cover and time of year was an important source of variability in faunal parameters. The effects of site and season were not additive or independent of each other. This interaction was obviously introduced by the dynamics of Spartina alterniflora growth and decline. It has been shown that variation in plant biomass and in production dynamics of local, highenergy marshes are markedly season-dependent, as in temperate latitudes (Lana et al. 1991). Interpretation of data generated by between-site comparisons or by studies on temporal variation in local associations is heavily dependent upon knowledge of this interaction. Useful working hypotheses concerning this system must consider that (1) between-site differences depend upon season, and (2) differences in faunal parameters from season to season depend upon which site is examined.

Our results suggest that the presence of below- or above-ground biomass, together with seasonal fluctuations in availability of detritus, which reflects Spartina alterniflora population dynamics, exerts a strong influence on the composition, abundance and persistence of invertebrate fauna in a euhaline, high-energy tidal flat of a subtropical estuary. Physico-chemical parameters, such as mean grain size, sediment organic content or silt-clay percentage, seem to play only a secondary role in determining local macrobenthic diversity and abundance. It is our intention, in the future, to consider the resource partitioning by local species in terms of feeding or mobility strategies and to assess the role played by biological processes, such as predation and recruitment dynamics, in the organization and maintenance of such associations.
Acknowledgements. This study was supported by CNPq (Brazilian National Research Council) under Grants 301532/ 84 to Paulo Lana and $820117 / 87$ to Claudia Guiss. Our special thanks to Sibelle Trevisan Disaró for her extensive help in field, lab and data-processing work. Our colleagues, Mário Barletta, Arno Blankensteyn, José Roberto Botelho, Ivan Britto, Elenice Gonçalves and Gisele Sessegolo, helped during the tedious sieving work. Computer facilities for data analyses were provided by Jean Valentin, Henry Louis Spach and Sergio Antonio Netto. Granulometric analysis was carried out by Carlos Roberto Soares, and José Claro Neto was most helpful with the drawings. We also thank Gustavo Melo, Theresinha de Jesus Absher, Maria Thereza Berardo and Marco Fábio Corrêa for identifying some macrofaunal or natant groups. Our sincere thanks to Dr Philip Gorin (Universidade Federal do Paraná) and Louise Squire for correcting the manuscript.

\section{LITERATURE CITED}

Adaime, R. R. (1978). Estudo da variacão estacional do 'standing-crop' e do repovoamento em um banco de Spartina alterniflora Loiseleur, 1807, no complexo estuarino-lagunar de Cananéia. Bolm Inst. Oceanogr., S. Paulo 27: 1-43

Bell, S. S. (1979). Short- and long-term variation in a high marsh meiofauna community. Estuar coast. mar. Sci. 9: $331-350$

Bell, S. S. (1980). Meiofauna-macrofauna interactions in a high salt marsh habitat. Ecol. Monogr 50: 487-505

Bloom, S. A. (1983). Seasonality and structure of a macrobenthic seagrass community on the Florida Gulf Coast. Int. Revue ges. Hydrobiol. 68: 539-564

Boesch, D. F., Wass, M. L., Virnstein, R. W (1976). The dynamics of estuarine benthic communities. In: Wiley, $M$. (ed.) Estuarine processes. Academic Press, New York, p. $177-196$

Brenchley, G. A. (1982). Mechanisms of spatial competition in marine soft-bottom communities. J. exp. mar Biol. Ecol. 60: $17-33$

Capehart, A. A. Hackney, C. T (1989). The potential role of roots and rhizomes in structuring salt marsh benthic communities. Estuaries 12: 119-122

Capitoli, R. R., Bemvenuti, C. E., Gianuca, N. M. (1978) Estudos de ecologia bentônica na regiāo estuarial da Lagoa dos Patos. I - As comunidades bentônicas. Atlântica 3: $5-22$

Daiber, F. C. (1977). Salt marsh animals: distribution related to tidal flooding, salinity and vegetation. In: Chapman, V. J. (ed.) Ecosystems of the world. I. Wet coastal ecosystems. Elsevier, Amsterdam, p. 79-108

Daiber, F. C. (1982). Animals of the tidal marsh. Van Nostrand Reinhold Company, New York

Dean, W. E., Jr. (1974). Determination of carbonate and organic matter in calcareous sediments and sedimentary rocks by loss on ignition: comparison with other methods. J. sedim. Petrol. 44: 242-248

Heck, K. L., Jr., Thoman, T. A. (1981). Experiments on predator-prey interactions in vegetated aquatic habitats. J. exp. mar. Biol. Ecol. 53: 125-134

Jackson, D. (1985). Invertebrate populations associated with Spartina anglica salt-marsh and adjacent inter-tidal mudflats. EBSA Bulletin 40: 8-14

Kneib, R. T (1984). Patterns of invertebrates distribution and abundance in the intertidal salt marsh: causes and questions. Estuaries 7: 392-412 
Kneib, R. T., Stiven, A. E. (1982). Benthic invertebrate responses to size and density manipulations of the common mummichog. Fundulus heteroclitus, in an intertidal salt marsh. Ecology 63: 1518-1532

Knoppers, B. A., Brandini, F. P., Thamm, C. A. (1987). Ecological studies in the Bay of Paranaguá. II. Some physical and chemical characteristics. Neritica 2: 1-36

Lana, P. C., Guiss, C., Disaró, S. T. (1991). Seasonal variation of biomass and production dynamics for above- and belowground components of a Spartina alterniflora marsh in the euhaline sector of Paranaguá Bay (southeastern Brazil). Estuar. coast. Shelf Sci. 32: 231-241

Levinton, J. S. (1972). Stability and trophic structure in deposit-feeding and suspension-feeding communities. Am. Nat. 106: 472-486

Lewis, F. G., III, Stoner, A. W. (1983). Distribution of macrofauna within seagrass beds: an explanation for patterns of abundance. Bull. mar. Sci. 33: 296-304

Long, S. P., Mason, C. F. (1983). Saltmarsh ecology. Blackie \& Son Ltd., Glasgow

Orth, R. J. (1977). The importance of sediment stability in seagrass communities. In: Coull, B. C. (ed.) Ecology of marine benthos. University of South Carolina Press, Columbia, p. 281-300

Orth, R. J., Heck, K. L., Jr., Montfrans, J. (1984). Faunal communities in seagrass beds: a review of the influence of plant structure and prey characteristics on predator-prey relationships. Estuaries 7: 339-350

Panitz, C. M. N. (1987). Perfil funcional da gramínea Spartina alterniflora no mangue do rio Itacorubi, Ilha de Santa Catarina, Florianópolis, Brasil $\left(27^{\circ} 35^{\prime} \mathrm{S}-48^{\circ} 31^{\prime} \mathrm{W}\right)$. Publ. Acad. Ciênc. Estado S Paulo 54(1): 100-116

Peet, R. K. (1974). The measurement of species diversity. A Rev. Ecol. Syst. 5: 285-307

Peterson, C. H., Peterson, N. M. (1979). The ecology of intertidal flats of North Carolina: a community profile. U.S. Fish and Wildlife Service, Office of Biological Sciences, FW5/ OBS-79/39, Slidell, Louisiana

Rader, D. N. (1984). Salt-marsh benthic invertebrates: smallscale patterns of distribution and abundance. Estuaries 7 . $413-420$

Sanders, H. L. (1960). Benthic studies in Buzzards Bay. III. The structure of the soft-bottom community. Limnol. Oceanogr. 5: $138-163$

Sanders, H. L. (1978). Florida oil spill impact on the Buzzards

This article was submitted to the editor
Bay benthic fauna: West Falmouth. J. Fish. Res. Bd Can. 35: $717-730$

Soriano-Sierra, E. J. (1990). Ecossistemas de marismas. III. A produçào primária. Publ. Acad. Ciennc. Estado S Paulo 71 (2): $150-157$

Stoner, A. W (1980). The role of seagrass biomass in the organization of benthic macrofaunal assemblages. Bull. mar. Sci. 30: 537--551

Subrahmanyam, C. B., Coultas, C. L. (1980). Studies on the animal communities in two north Florida salt marshes. Part III Seasonal fluctuations of fish and macroinvertebrates. Bull. mar. Sci. 30: 790-818

Subrahmanyam, C. B., Kruczynski, W. L., Drake, S. H. (1976). Studies on the animal communities in two north Florida salt marshes. Part II. Macroinvertebrate communities. Bull. mar. Sci. 26: 172-195

Suguio, K. (1973). Introduçào à sedimentologia. Editora Edgard Blucher Ltda, Editora da Universidade de Sào Paulo, Sào Paulo

Takeda, A. M. (1988). Estrutura de associaçôes macrobênticas da Spartina alterniflora Loiseleur, 1807 no complexo estuarino-lagunar de Cananéia. Doctoral thesis, Oceanographic Institute, Sào Paulo University

Tararam, A. S., Wakabara, Y (1987). Benthic fauna living on Spartina alterniflora of Cananéia estuarine region (2502 S-47 56 W). Bolm Inst. Oceanogr., S Paulo 35: 103-113

Teal, J. M. Wieser, W. (1966). The distribution and ecology of nematodes in a Georgia salt marsh. Limnol. Oceanogr 11 $217-222$

Wiegert, R. G., Pomeroy, L. R. (1981). The salt-marsh ecosystem: a synthesis. In: Pomeroy, L. R., Wiegert, R. G. (eds.) The ecology of a salt marsh. Springer-Verlag, New York, p. $219-230$

Wiltse, W I. Foreman, K. H., Teal, J. M., Valiela, I. (1984). Effects of predators and food resources on the macrobenthos of salt marsh creeks. J. mar Res. 42: 923-942

Young, D. K., Buzas, M. A, Young, M. W (1976). Species densities of macrobenthos associated with seagrass: a field experimental study of predation. J. mar Res. 34: 577-592

Zimmerman, R. J., Minello, T J. (1984). Fishery habitat requirements: utilization of nursery habitats by juvenile penaeid shrimp in a Gulf of Mexico salt marsh. In: Copeland, B. J., Hart, K., Davis, N. (eds.) Research for managing the nation's estuaries. Proceedings of a Conference in Raleigh, North Carolina, p. 371-383

Manuscript first received: September 28, 1990

Revised version accepted: April 12, 1991 